\title{
Recreational Experiences for Teaching Basic Scientific Concepts in Primary Education: The Case of Density and Pressure
}

\author{
Guadalupe Martínez Borreguero ${ }^{1 *}$, Francisco Luis Naranjo Correa ${ }^{1}$, Milagros Mateos Núñez ${ }^{1}$, \\ Jesús Sánchez Martín ${ }^{1}$ \\ ${ }^{1}$ Department of Didactics of Experimental Sciences, University of Extremadura, Avda. De Elvas s/n, 06006 Badajoz, SPAIN
}

Received 1 April 2018 • Revised 9 July 2018 • Accepted 27 July 2018

\begin{abstract}
Recreational science experiences were used as a teaching tool in the learning process of two basic concepts at primary school level: pressure and density. These kinds of resources are widely spread as hook methodologies in non-formal educative areas, but this work puts them into the formal school space. A comparative study in four primary students groups was carried out, involving up to 82 students of 10-11 years old. Control groups were submitted to the traditional oral-based classroom whereas the experimental groups underwent a novel teaching methodology totally based on recreational science experiences. The results showed that although the immediate knowledge acquisition is similar in both cases, the use of recreational science inside classroom enhances the remembrance of the learning experience and probably links positive emotions to science education.
\end{abstract}

Keywords: recreational science, meaningful learning, methodology, primary school

\section{INTRODUCTION}

Science is considered one of the foundations of culture, given its importance in the development of the individual and our society. Although there is a positive appreciation of science by society, most students do not show interest in studying science subjects, especially as their age and the instruction process increase (Vázquez \& Manassero, 2011). For instance, one of the last PISA report in science (OECD, 2012), shows that there exists a lack of interest in young people for learning science. The origin of this situation can be found, among other causes, in the way science is taught, as some authors already alerted ten years ago (Rocard, 2007). Some authors (Osborne, Simon, \& Collins, 2010) highlight the need to identify the factors that make science teaching attractive and exciting to students. Specifically, it is important to know which activities can promote positive emotions and attitudes towards science subjects. Others studies (Mellado et al., 2014) note that one of the main problems in the teaching of science in schools is the negative attitude of many students towards it. This initial disinterest is caused sometimes by the stereotype of science concepts being something that only a privileged few can understand. Murphy and Beggs (2003) suggest additional factors that could affect this negative attitude, such as the teacher or the lack of practical work.

Recent data (FECYT, 2014) still evidenced the need for taking care of the scientific education even since the earlier educative stages, because almost a quarter of the Spanish population presents a null interest on scientific issues. One of the main reasons for this lack of interest is their misunderstanding. In the same sense, almost a half of this sample thinks his or her scientific educative level is low or very low. Some responsibility of such situation may be placed at school, and some responsible of these ideas may be teachers and their methodologies in science teaching. In this line, some authors (Kelly, 2000) indicated that the teaching and learning processes of science acquired in formal and traditional education should be reinforced with other sequences of activities. For this reason, there is a need for a didactic change: science traditional teaching, based on theoretical talks, abstract concepts, and numeric problems resolution versus new active methodologies, which allow students to understand scientific concepts in a meaningful context.

(C) 2018 by the authors; licensee Modestum Ltd., UK. This article is an open access article distributed under the terms and conditions of the Creative Commons Attribution License (http://creativecommons.org/licenses/by/4.0/). $\square$ mmarbor@unex.es (*Correspondence) $\boldsymbol{\nabla}$ naranjo@unex.es $\boldsymbol{\nabla}$ milagrosmateos@unex.es 


\section{Contribution of this paper to the literature}

- It is necessary at the primary school level (6-12 years) to carry out more active methodologies that promote meaningful learning of concepts and generate positive emotions towards science.

- This work analyses the didactic usefulness, from a cognitive and emotional point of view, of the inclusion of practical activities of recreational physics, carried out with a playful character in the formal classroom.

- Two parallel experimental designs were carried out simultaneously, with control and experimental groups. The inclusion of fun practical work leads the student to assimilate and learn more effectively the scientific contents, thus lasting the learning over time.

\section{THEORETICAL FOUNDATION}

\section{The Importance of a Positive View towards Science to Promote a Meaningful Learning at Early Ages}

The ENCIENDE project for teaching science in school (COSCE, 2011) considers the importance of science concepts acquired at early ages and takes into account all these previous considerations. This project regards with several proposals that could be used to promote a real modification of the teaching-learning process of science. Some of them are: (1) the teaching of science should include activities that allow the students to enforce the theoretical concepts; (3) a connection between contents and real life; (4) the collaboration between the educative and the scientific communities, involving researchers and universities in a renewed school science-teaching pedagogy. These results clearly suggest that the way in which children and young people are taught about science has a negative effect on their own view of science. For this reason, it is necessary to make appropriate proposals to increase the interest of the population in general in scientific subjects and to promote scientific vocations with science-related activities inside and outside the schools (Olsen et al. 2011).

Obviously, one of the main challenges science education is to preserve the interest children bring to the classroom on scientific issues the first day they see, for example, a plant growing in a paper cup when they are at kindergarten. Another one should be to encourage the curiosity, the pleasure for discovering or explaining natural phenomena according to a scientific thinking. No one could deny that it is difficult to pursue these targets, regarding the awakens of scientific vocations, only through the traditional educational instruments, most of them based on the oral transmission of knowledge. In this regard, some studies (Hart, Mulhall, Berry, Loughran, \& Gunstone, 2000) indicate that, in schools, experiments can motivate students and reinforce concepts through the formulation of hypotheses.

A new need for novel and innovative tools has arisen in the last years, moving the centre of interest from the teacher to the student. This is in agreement with the classical constructivism theories, according to those one of the purposes of education is to enable students to understand and generate knowledge, avoiding rote learning and promoting meaningful learning (Ausubel, 2000; Martinez, Naranjo, Pérez, Suero, \& Pardo, 2017). Additionally, Novak $(1984,1998)$ suggested that the changes that are taking place all over the world require innovations in education that focus on the nature and power of meaningful learning. It is in this new context where there is a need to review the traditional concepts of teaching and learning. In this sense, research in science education has amongst its purposes to improve and strengthen the learning process for enhancing the meaningful construction of knowledge within the students.

There have been many investigations conducted over the years about what is the best methodology for teaching students as well as the need to take into account the emotional domain and emotions generated in the teaching and learning of these subjects (Mellado et al., 2014). Consequently, teachers should make an effort to: search and integrate new methods of teaching and learning science in the school, the assessment of student learning in science education, and the creation of new guidance intervention evidence-based in science field. On the knowledge society in which we are currently living, these methodologies should arouse the interest of students to make learning active, participatory, enjoyable and even fun. As a matter of fact, science education cannot be a rigid academic framework, but a dynamic subject that can be taught both in and out of school. It is important, above all, to bring science education to the outside world, where the students spend their time once they finish their formal classes (Francl, 2012).

\section{A Teaching Approach to Practical Work in Science: Recreational Activities}

In most classrooms, science and technology are not learned in a meaningful way and, generally, the knowledge acquired is not applied to everyday life (Duit \& Pfund, 1998), which promote negative emotions in students towards 
science (Osborne, Simon, \& Collins, 2010). In addition, some teaching strategies used in the classroom of many schools do not allow the practical treatment of the experimental sciences, either because of the lack of time or because of the lack of laboratory equipment. Most of the science teaching processes in primary schools (6-12 years old) are usually based on traditional teaching, in which the textbook worksheets and activities are proposed. These activities are usually for the consolidation and reinforcement of the contents that have been explained through presentations or readings by the teacher. In general terms, these activities do not favour the creativity of the students and usually promote a rote learning of the contents instead of a meaningful learning. Some authors (García Barros \& Martínez Losada, 2003) indicate that there is often a lack of problem-solving activities and experimentation in schools, especially in the primary education stage (6-12 years). On the other hand, (Garritz, 2005) indicates that traditional science teaching, as is currently being carried out in most schools, only develops guided scientific knowledge and does not make students question what science is, how it works internally, how it is developed, how reliable the knowledge they learn is, how it was obtained and what benefits it brings to society. In many cases, the scientific knowledge acquired by the students during a traditional training does not allow for a conceptual change in the misconceptions presented by the students, which implies that the concepts are not learned meaningfully and end up forgotten over time. Strike and Posner (1990) show in their studies that previous ideas can be maintained even after a teaching explicitly proposed to eradicate them. Others (Carmichael, Driver, Holding, Phillips, Twigger \& Watts, 1990) point out that practical work can be used to promote conceptual change in students.

Current curricular projects aim to go beyond traditional approaches. In the framework of this work, "traditional" refers to a teaching which is generally based on an exposition of the lesson in class. The students follow a textbook, and they usually just memorize and solve the proposed worksheets and activities. This methodology promotes a passive attitude of the student in the classroom; it does not arouse an interest in science and it leads to a part of the class time being lost in routine expositions that can be found in any textbook. For this reason, several reports at international level insist that it is not possible to achieve an increase in the quality of science education, as well as effective learning in it, without a change in the way in which learning is traditionally carried out in schools (European Commission, 2004, 2007).

Based on this background, it is considered necessary to carry out in the classrooms other more active methodologies that promote a meaningful learning of the scientific concepts explained and that, at the same time, generate positive emotions and attitudes towards science in the students. However, there are two conflicting viewpoints regarding the practical treatment of science in the early school years (Latorre \& Fortes, 1990). The first points out that experimentation is not appropriate in the infantile or primary stage because at this age there is no formal thinking that helps to understand and carry out the experimental techniques. The second viewpoint, which we want to examine in this research, is that practical experience will undoubtedly provide meaningful learning for children of this age. Some research (Marulanda \& Gómez, 2006) considers that facing the student to the physical phenomenon would be a very suitable didactic strategy for the student to ask questions about the phenomenon, with the answers found enhancing the motivation for the elaboration of formal learning. However, studies such as those of Hodson $(1992,1993)$ consider it inappropriate to carry out excessively guided practical work, lacking in many of the fundamental aspects for the construction of scientific knowledge. This author noted that there was little evidence of the effectiveness of practical work in the teaching of scientific concepts. More recently (Abrahams \& Millar, 2008) the effectiveness of practical work has been explored through the analysis of different science lessons in secondary schools. Millar (2010) highlighted in his study that the purpose of practical work is to help students relate the world of ideas to the world of objects and observables. Toplins and Allen (2011) carried out a critical analysis of practical work in classrooms at the secondary stage (12-16 years). Basheer, Hugerat, Kortam and Hofstein, (2016) analysed the effectiveness of practical activities, and concluded that they were useful both in understanding the scientific concept and in improving attitudes and motivation for science learning in a sample of secondary school students. Yakar and Baykara $(2014)$ discussed in their study that research-based laboratory practices improve the skills of the scientific process, as well as creativity, emotions and attitudes towards science. Along these lines, other authors (Bulunuz, 2012) carried out a study on the advantages of using practical scientific activities of a playful nature with a sample of teachers in training. This author concludes that this type of activities encourage interest, curiosity for science and the ability to use scientific reasoning. Other research analysed how through well-planned recreational activities, scientific skills can be developed in early childhood education students (Ayvaci, 2010). On the other hand, Bozdogan and Yalcin (2009) studied the relationship between the interest shown and the academic performance of primary school students in practical exhibitions in science museums. Fortus and Vedder-Weiss, (2014) note that studies have shown that experimenting with science in extracurricular settings contributes greatly to scientific literacy in general (Duschl, Schweingruber, \& Shouse, 2007). They also claim that much of what people know about the world comes from experiences outside of school. A recent study (Oppermann, Brunner, Eccles, \& Anders, 2018) focused on uncovering young children's motivational beliefs about learning science. Specifically, their results show that older children are more self-confident with science, arguing that perhaps it is because they had greater experience with science that they have greater motivational beliefs. Specifically, young children's early motivational beliefs about science have been shown to 
predict their future engagement and interest in elementary school (Leibham, Alexander, \& Johnson, 2013). This is especially relevant, as children's motivation to learn can become a predictor of their future achievements (Britner \& Pajares, 2006). That is, if in elementary school the students manifest negative emotions toward science, then they will probably not engage in science in the future (Saçkes, Trundle, Bell, \& O'Connell, 2011; Simpkins, Davis-Kean, \& Eccles, 2006).

Based on these previous studies, we intend to further study the usefulness, from a didactic point of view, of practical activities when they are carried out with a playful and recreational character in primary school. These activities are similar to those that take place in non-formal contexts, where students show admiration and great motivation for science, in contrast to their decreasing interest in it when they are subjected to a traditional formal education. In this sense, we think it becomes increasingly necessary to conduct motivational experiences in the science teaching and learning process at any educational level, but even more relevant it is at primary school. At this educational level the first attitudes and emotions towards science are being shaped, and a good teachinglearning process is therefore necessary at this stage. As Mantzicopoulos, Patrick, and Samarapungavan (2008) point out in their study, when children are given the opportunity to participate in scientific research, they enjoy science and generally feel competent to learn it. The main aim of the current work is to propose and analyse the development of recreational science experiences, with practical and hands-on activities inside the primary school science classroom.

\section{METHODOLOGY OF RESEARCH}

\section{Research Problem}

Usually, most of students of our Faculty, future elementary teachers, reach the last year of their Degree lacking both interest and knowledge in the area of physics and chemistry (Brígido, Borrachero, Bermejo, \& Mellado, 2013). For this reason, one of our goals is to teach them how to arouse interest in physics in their future elementary students (6-12 years old), so they can pass on to these latter a meaningful and closer to reality learning. In this sense, the work presented here is framed within the context of the final project to obtain the degree in elementary education, where experiences of recreational physics have been developed and implemented in the primary classroom to test their educational value in learning basic concepts of physics. Works related to the characteristics of recreational science or Hands-on Science Activities and its teaching possibilities (both formal and non-formal) have been recently published (Costa \& Dorrio, 2010; Dorrío, Rodríguez, Fernández, Ansín, \& Lago, 2007; Esteves, Cabral, \& Costa, 2008; Garcia-Molina, 2011; McComas, 2011). Currently, the use of recreational science, hands-on science activities or science museums as a teaching element is increasing (Kelly, 2000; Lewin, 2011; Lozano, GarciaMolina, \& Solbes, 2007; Paul, Lederman, \& Groß, 2016). The recreational science is a highly motivating teaching resource, which shows one of the different ways of learning science through striking situations and suggestive experiences. Other studies (Bulunuz, 2012; Bulunuz \& Jarrett, 2008; Palmer, 2009) showed the evolution in attitudes to science of primary school teachers when using hands-on science activities.

The research questions we ask are therefore the following ones:

1. Did the recreational science experiences conducted in the primary school classroom facilitate or enhance the understanding of the scientific concept?

2. Did the academic performance of primary school students who do this kind of experiences improve?

\section{Objectives}

The current work is focused on the proposal of enhanced methodologies for science education at Primary school level. In this sense, the main aim of this research is to check the positive influence of implementing an educational strategy based on recreational science experiences in the learning process of two basic scientific concepts: pressure and density. To achieve this goal, the following specific objectives were set out:

Specific Objective 1 (SO1): Know the previous ideas of students from 5th grade on the concepts of density and pressure.

Specific Objective 2 (SO2): Analyse the best way students acquire the involved concepts: by performing scientific recreational physics experience in the classroom or by traditional oralbased explanations.

Specific Objective 3 (SO3): Analyse to what extent recreational science is a motivational activity for making the students' interest on science arise.

Specific Objective 4 (SO4): Analyse the persistence over time of their concept learning. 


\section{Sample of Research}

Two parallel experimental designs were carried out simultaneously, with control and experimental groups, pretest and post-tests. The sample involved $825^{\text {th }}$ grade students (10-11 years old). The sample used has been of intentional type through non-probabilistic sampling for convenience, due to the ease of access to the sample under study. These students were divided into 4 groups belonging to two different schools in the area. These groups can be considered as homogeneous and equivalent in terms of their degree courses, capabilities, discipline, and academic performance in their previous courses. However, the scientific topics to work on (pressure and density) were not studied previously, so the potential interference effect of academic performance or marks on this specific topic was minimized.

According to a general experimental-control research methodology, recreational science experiences were used in two of the involved groups as an innovative educational technique, and a control group (with the classical oralbased exposition teaching method) was set for each experimental one to contrast the influence of the teaching methodology in the knowledge acquisition. In the different classes of each school it has been used a different methodology to verify its educational value in explaining basic concepts of physics (density and pressure). Two groups served as experimental groups (E.G.1 and E.G.2), where it was used a recreational science teaching methodology, and the other two groups served as control groups (C.G.1 and C.G.2), where a more traditional teaching methodology was used. All the groups, both control and experimental, had the same time allotted for the explanation of the selected concepts. Thus, it was possible to analyse whether there were any differences in the learning and satisfaction of the students of each group. 10-11 year old students were chosen to conduct this study, because we think it is the proper age to start supporting scientific knowledge with recreational physics.

The current work is placed in the curricular subject "Natural Sciences", where pressure and density are presented for the first time. The recreational science experiences (Experimental groups) have been carried out by using recycled materials, easy to get, in order to ensure its reproducibility outside school. The purpose of these recreational science experiences, used in the experimental groups, was to show the student that with simple supplies it is possible to conduct fun experiments by which they can learn concepts of physics. The experiments used were carried out by teachers in training who gave the activity a playful character, similar to what is done at science fairs or in more informal projects such as the "Researchers' Night". The experiments carried out were accompanied by an observation sheet that focused the attention of the students. The observation sheet contained questions to be asked before, during and after the experience, so that the students could raise questions or formulate and validate hypotheses that would allow them to acquire the scientific content required. However, in the control groups, the concepts were explained by their teachers following their usual traditional classroom methodology. The corresponding theoretical explanations, readings from the student's textbook and the worksheets and activities proposed in them were used.

Figure 1 shows a concept map of how the work was performed. 


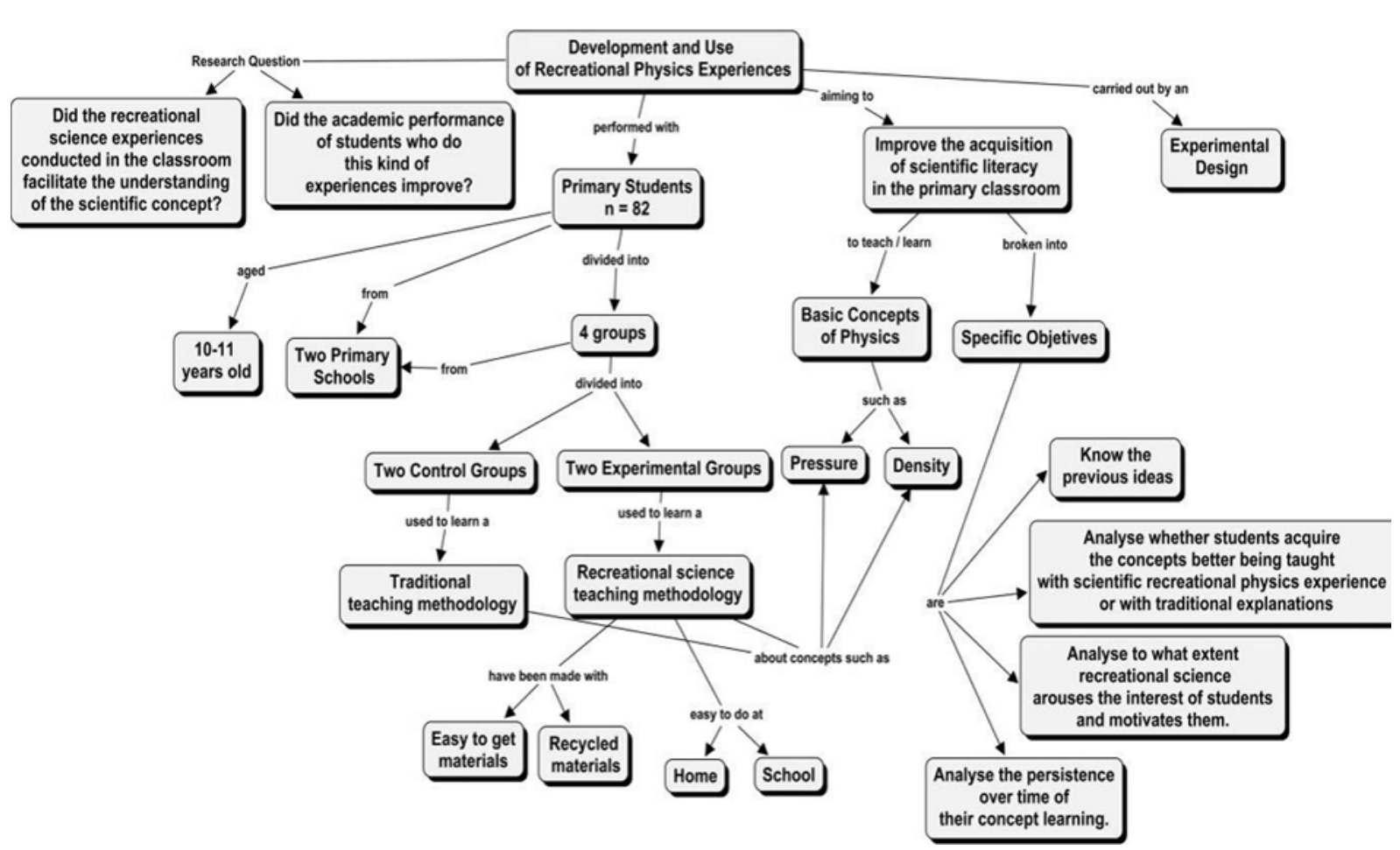

Figure 1. Concept map- Experimental design

Table 1. Experimental data design

\begin{tabular}{|c|c|c|c|c|c|c|c|}
\hline School & $\mathbf{n}$ & Group & Teaching Methodology & $\begin{array}{l}\text { Developed } \\
\text { Concept }\end{array}$ & $\begin{array}{c}\text { Initial } \\
\text { Instrument }\end{array}$ & $\begin{array}{c}\text { Final Instrument } \\
\text { (after the } \\
\text { explanation) } \\
\end{array}$ & $\begin{array}{l}\text { Final Instrument } \\
\text { (two months } \\
\text { after post-test I) }\end{array}$ \\
\hline $\begin{array}{l}\text { School 1- } \\
\text { Class } 1 \\
\end{array}$ & 21 & $\begin{array}{c}\text { Control Group } 1 \\
\text { (CG1) }\end{array}$ & $\begin{array}{c}\text { Traditional Teaching } \\
\text { Methodology (Teacher 1) }\end{array}$ & Density & Pre-test 1 & Post-test I_1 & Post-test II_1 \\
\hline $\begin{array}{l}\text { School } 1- \\
\text { Class } 2\end{array}$ & 21 & $\begin{array}{l}\text { Experimental } \\
\text { Group } 1 \text { (EG1) }\end{array}$ & $\begin{array}{c}\text { Recreational Sciences } \\
\text { Teaching Methodology } \\
\text { (Teacher } 1 \text { ) }\end{array}$ & Density & Pre-test 1 & Post-test I_1 & Post-test II_1 \\
\hline $\begin{array}{l}\text { School } 2- \\
\text { Class } 1\end{array}$ & 20 & $\begin{array}{c}\text { Control Group } 2 \\
\text { (CG2) }\end{array}$ & $\begin{array}{c}\text { Traditional Teaching } \\
\text { Methodology } \\
\text { (Teacher 2) }\end{array}$ & Pressure & Pre-test 2 & Post-test I_2 & Post-test II_2 \\
\hline $\begin{array}{l}\text { School } 2- \\
\text { Class } 2\end{array}$ & 20 & $\begin{array}{l}\text { Experimental } \\
\text { Group } 2 \text { (EG2) }\end{array}$ & $\begin{array}{c}\text { Recreational Sciences } \\
\text { Teaching Methodology } \\
\text { (Teacher 2) }\end{array}$ & Pressure & Pre-test 2 & Post-test I_2 & Post-test II_2 \\
\hline
\end{tabular}

\section{Measuring Instrument and Procedures}

In order to measure the knowledge acquisition, a measuring instrument was designed.

- A pre-test (1) to check the initial knowledge of the students about the concept of density, performed by the students from school 1 .

- A pre-test (2) to check the initial knowledge of the students about the concept of pressure, performed by the students from school 2.

- A post-test (I_1) at school 1 and 2, and a post-test (I_2) at school 3 and 4 to check the acquired knowledge about the concept after the explanation with different methodologies.

- A post-test (II_1 or II_2, depending on the school), two month after post-test I, to check if students remembered the concept learned by the different methodologies.

Each of the above tests consisted of five questions related with the concept of density or pressure. The questions were written on so that the student could answer freely, so they could also express their previous ideas, mistakes or misunderstandings. Table 1 summarizes the experimental data design. 


\section{Hypotheses}

In order to respond to the research questions (see above), the working hypotheses tested in the current study were as follows:

- Hypothesis 1 (H1): The selected students in both schools do not know yet the concepts of density or pressure. (We determined this using a test of prior knowledge, pre-test (1) in which the students were unable to define these concepts)

- Hypothesis 2 (H2): The students from the experimental groups (teaching based on recreational physics) acquire the scientific concept explained (density or pressure) better than students from the control group (traditional teaching). (We determined this using a post- test I-1 and post-test I_2)

- Hypothesis 3 (H3): The students from the experimental groups remember the concepts explained a longer time than the students from the control groups. (We determined this using a post- test II-1 and post-test II_2)

\section{Data Analysis}

To test the research hypotheses, the post-test scores were subjected to a descriptive statistical analysis, which included verifying the normality of their distribution. The resulting statistics allowed to determine the knowledge acquisition attained by the students of each group and to quantify the increment in learning achieved by the experimental groups (if so) compared to the control groups. These analyses were carried out using the IBM SPSS software.

\section{RESULTS OF RESEARCH}

\section{Analysis of the Measuring Instruments}

First, the results regarding the validity and reliability of the questionnaires used in the research are presented based on the analyses recommended by other studies (Ding \& Hershberger, 2002; Ding, Chabay, Sherwood, \& Beichner, 2006; McColgan, Finn, Broder, \& Hassel, 2017).

With regard to the validity of the measuring instruments, they are considered valid if the knowledge they measure is related to the purpose of the test and to the specific domain of the contents measured in the study. Since validity cannot be assessed statistically, it was determined by consensus of opinions of an expert group. Specifically, to establish the validity, the draft questionnaires were given to a group of 6 professors who were experienced in teaching experimental sciences. The objective was to check whether the questions included in the questionnaires were adapted to the level of the participating subjects, or whether their phrasing was appropriate for the research, among other parameters to be evaluated. Specifically, as some studies suggest (Ding \& Hershberger, 2002), a concordance test was carried out among the experts, who were provided with eight assessment criteria on which they had to mark their agreement (scored as 1) or disagreement (scored as 0 ). The degree of concordance is calculated as the result of the number of total agreements divided by the sum of the number of total agreements plus the total number of disagreements. The value obtained in this study was 0.93 , a very good degree of concordance according to the bibliography.

In addition, several psychometric tests were carried out in order to highlight the reliability of the instruments within the study, following the recommendations of several authors (Kline, 2015; Ding et al., 2006; McColgan et al., 2017; Melo, Sánchez, Cañada, \& Martínez, 2016). Statistical tests were performed focusing on the evaluation of the items of the questionnaire, such as the difficulty index, discrimination index, point-biserial coefficient and Ferguson's delta using the formulas specified in the previous studies. Table 2 shows the values obtained and the recommended values (Ding \& Beichner, 2009; Kline, 2015) of the calculated indices. As shown, all values are within the range recommended in the literature. 
Table 2. Statistical analysis of the measuring instruments. Mean index values (left columns) and recommended value range (right column)

\begin{tabular}{lccccc}
\hline & \multicolumn{2}{c}{ Topic 1: Density } & \multicolumn{2}{c}{ Topic 2: Pressure } & \\
\hline & Post-test I & Post-test II & Post-test I & Post-test II & Desired Range \\
\hline $\begin{array}{l}\text { Mean item difficulty (P) } \\
\begin{array}{l}\text { Mean discrimination } \\
\text { index 1 (D1) }\end{array}\end{array}$ & 0.76 & 0.65 & 0.67 & 0.70 & {$[0.3-0.9]$} \\
\hline $\begin{array}{l}\text { Mean discrimination } \\
\text { index 2 (D2) }\end{array}$ & 0.44 & 0.43 & 0.51 & 0.42 & $\geq 0.3$ \\
\hline $\begin{array}{l}\text { Mean point-biserial } \\
\text { coefficient (r) }\end{array}$ & 0.43 & 0.66 & 0.72 & 0.66 & $\geq 0.5$ \\
\hline \begin{tabular}{l} 
Ferguson's delta $(\delta)$ \\
\hline
\end{tabular} & 0.93 & 0.37 & 0.47 & 0.39 & $\geq 0.2$ \\
\hline
\end{tabular}

With respect to the mean difficulty indexes $(P)$ of the questionnaires, they indicate the degree of difficulty of the questionnaires, so that the higher the index, the easier the question asked. The difficulty index of a specific item is calculated by dividing the correct answers obtained in the item by the number of students who answered the item, that is, $P_{i}=N_{\text {correct }} / N_{i}$. This index was calculated for all the questions that made up the questionnaires, obtaining in all of them similar values of difficulty that were within the established ranges. These specific difficulty indices are averaged over all questions of the questionnaire to obtain its mean difficulty index. Table 2 shows that the mean values obtained are around 0.6 or 0.7 , so that in general, the degree of conceptual difficulty of the instruments as a whole is suitable for research.

With regard to discrimination indices $(D)$, they express the extent to which the instrument differentiates between students who know more and those who know less. First, the discrimination index 1 (D1) was calculated for all the items included in the instruments. The discrimination index 1 measures the discriminatory power of each item in a test, that is, it allows us to conclude whether the test can distinguish those subjects with more solid knowledge who respond correctly from those whose understanding is weaker. The aim was to check whether there were questions that were too easy or too difficult that did not discriminate and therefore did not contribute to the reliability of the instruments. The discrimination index 1 for a question takes the difference between the fraction of correct answers to that question from students in the top quartile $N_{i T}$ and from those in the bottom quartile $N_{i B}$ : $D 1_{i}$ $=\left(N_{i T}-N_{i B}\right) /\left(0.25 N_{i}\right)$. The mean discrimination index 1 is the mean of the discrimination indices for all questions. The values obtained as specified in Table 2 are around 0.4 or 0.5 , which indicates a good index of discrimination.

The discrimination index 2 (D2) indicates the proportion of correct answers in the group of students with the best marks in relation to the total number of correct answers, $D 2_{i}=N_{i T} /\left(N_{i T}+N_{i B}\right)$. This index tells us to what extent a question helps to distinguish between those who know the most and those who know the least, regardless of how easy the question is. It can be considered satisfactory if it is at least 0.50 , which means that more than half of the respondents belong to the group that knows the most. In this work this is the case for all questions. Specifically, we have obtained values around 0.65 or 0.70 , which are considered good in the literature.

The point-biserial coefficient $(r)$ shows the correlation between the subjects' scores on an item and the scores on the entire test. It is calculated $r=\left(M_{p}-M_{q}\right) \sqrt{p q} / \sigma_{t}$, where $M_{p}$ is the whole-test mean for students answering the item correctly, $M_{q}$ is the whole-test mean for students answering the item incorrectly, $\sigma_{t}$ is the standard deviation for the whole test, $p$ is the proportion of students answering correctly and $q$ is the proportion of students answering incorrectly. Thus, $r$ has a range between $[-1,+1]$. If an item is positively correlated with the entire test, it means that subjects with high overall scores are more likely to respond than subjects with low overall scores. The average point-biserial coefficient is around 0.37 or 0.47 , so it also meets the recommended range.

Another source of evidence was the calculation of Ferguson's delta $(\delta)$, the ratio between the discriminations made by a test and the maximum number such a test could provide. The coefficient is calculated as

$$
\delta=\frac{N^{2}-\sum_{i=1}^{n} f_{i}^{2}}{N^{2}-\frac{N^{2}}{(n+1)}}
$$

where $f_{i}$ is the frequency of cases at each score, $N$ is the number of subjects and $n$ is the number of items. The value of $\delta$ ranges from 0 (when all individuals score the same) to 1 (when there is a rectangular distribution). The literature indicates that a test offers good discrimination power if delta is greater than 0.9 . The questionnaires in the study have an index of approximately 0.9 , so in general terms the instruments offer good discrimination power.

\section{Comparative Analysis of the Results Obtained by the C.G. and the E.G.}

The results obtained by each of the control and experimental groups in the different measuring instruments are shown below, as well as the comparative analysis between them. 
Table 3. Results in the Post-test I

\begin{tabular}{|c|c|c|c|c|}
\hline \multirow{2}{*}{$\begin{array}{c}\text { Post-test I } \\
\text { (after the explanation) }\end{array}$} & \multicolumn{2}{|c|}{ Topic 1: Density } & \multicolumn{2}{|c|}{ Topic 2: Pressure } \\
\hline & CG1 & EG1 & CG2 & EG2 \\
\hline $\mathrm{N}$ & 21 & 21 & 21 & 21 \\
\hline Mean & 7.71 & 7.52 & 7.90 & 7.42 \\
\hline Std. Error Mean & 0.42 & 0.39 & 0.40 & 0.34 \\
\hline Std. Deviation & 1.92 & 1.78 & 1.84 & 1.57 \\
\hline
\end{tabular}

Table 4. t-test for Equality of Means - Comparing both Post-tests I

\begin{tabular}{lccccccc}
\hline & $\mathbf{t}$ & df & Sig. (2-tailed) & $\begin{array}{c}\text { Mean } \\
\text { Difference }\end{array}$ & $\begin{array}{c}\text { Std. Error } \\
\text { Difference }\end{array}$ & \multicolumn{2}{c}{ 95\% Confidence Interval of the Difference } \\
\hline Topic 1: Density & 0.333 & 40 & 0.741 & 0.190 & 0.572 & -0.966 & Upper \\
\hline Topic 2: Pressure & 0.902 & 39.006 & 0.372 & 0.476 & 0.527 & -0.591 & 1.346 \\
\hline
\end{tabular}

Table 5. Results in the Post-test II

\begin{tabular}{ccccc}
\hline \multirow{2}{*}{ Post-test II } & \multicolumn{2}{c}{ Topic 1: Density } & \multicolumn{2}{c}{ Topic 2: Pressure } \\
\cline { 2 - 5 } & CG1 & EG1 & CG2 & EG2 \\
\hline $\mathrm{N}$ & 21 & 21 & 21 & 21 \\
\hline Mean & 5.90 & 7.24 & 5.43 & 6.66 \\
\hline Std. Error Mean & 0.35 & 0.38 & 0.42 & 0.42 \\
\hline Std. Deviation & 1.60 & 1.73 & 1.91 & 1.93 \\
\hline
\end{tabular}

Table 6. t-test for Equality of Means - Comparing both Post-tests II

\begin{tabular}{lccccccc}
\hline & $\mathbf{t}$ & $\mathbf{d f}$ & $\begin{array}{c}\text { Sig. } \\
\text { (2-tailed) }\end{array}$ & $\begin{array}{c}\text { Mean } \\
\text { Difference }\end{array}$ & \multicolumn{2}{c}{$\begin{array}{c}\text { Std. Error } \\
\text { Difference }\end{array}$} & \multicolumn{2}{c}{ 95\% Confidence Interval of the Difference } \\
\hline Topic 1: Density & -2.58 & 40 & 0.013 & -1.333 & 0.515 & -2.375 & Lower \\
\hline Topic 2: Pressure & -2.68 & 39.57 & 0.011 & -1.523 & 0.567 & -2.671 & -0.291 \\
\hline
\end{tabular}

The results obtained in the pre-tests of all groups showed that students had no initial knowledge about the concepts of density or pressure, which allowed us to establish a common starting point between control and experimental groups. This initial result obtained from data corresponding to both Pre-tests (1 and 2) allow us to accept Hypothesis $1(\mathrm{H} 1)$ posed at the beginning of this research: "The selected students in both schools do not know yet the concept of density or Pressure."

Table 3 shows the mean, standard error mean and standard deviation of post-test I performed once each didactic intervention was performed on their different groups.

If we note Table 3 and compare the results of the post-test performed immediately after the didactic interventions, it is revealed that students in all groups, both control and experimental, increase significantly the number of correct answers from the initial pre-test, where the results were practically zero in all groups. To check if the differences between the means of the groups that are seen in Table 3 are statistically significant, we used SPSS and conducted the normality Kolmogorov-Smirnov test to check if the scores distribution were normal, in order to choose a parametric or non-parametric contrast of means.

The results of the normality test showed that there existed a normal distribution, so a Student $t$ test for independent samples has been used for comparison between groups. The results are shown in Table 4 .

We can see in Table 4 that the obtained significance is greater than 0.05 for both topics. Specifically, it is 0.741 for item 1 and 0.372 for item 2 . Therefore, we can affirm that on both post-test I there are no statistically significant differences in the scores between control groups and experimental groups. This suggests that the traditional methodology and the methodology based on recreational physics experiences are a priori equally effective. Given these results, Hypothesis 2 (H2) proposed in this research cannot be accepted: “The students from the experimental groups (teaching based on recreational physics) acquire the scientific concept explained (density or pressure) better than students from the control group (traditional teaching)."

However, the analysis of data from the second post-test, which took place two months after the educational intervention, has revealed that the experimental groups achieved better academic results than the control groups. Table 5 shows the mean, standard error mean and standard deviation of post-test II from both selected topics.

The results listed in Table 5 suggest certain differences between the control groups and the experimental groups. To verify whether the differences are statistically significant, first we check normality with the Kolmogorov-Smirnov test and subsequently we carried out a Student t-test. The results of this test are shown in Table 6 . 


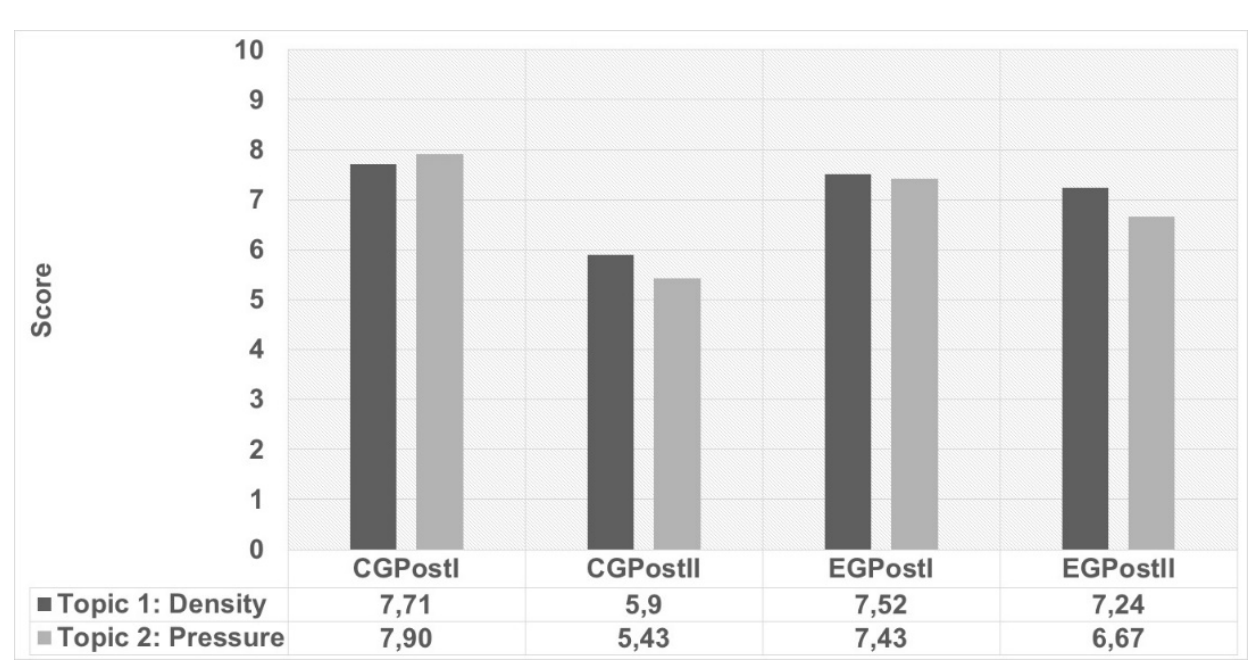

Figure 2. Comparison of scores between the groups (Pre-test, Post-test I and Post-test II)

Table 7. t-test for Equality of Means - Comparison of Post-test I with Post-Test II in each group and each topic under study

\begin{tabular}{cccccccc}
\hline Groups & t & df & $\begin{array}{c}\text { Sig. } \\
\text { (2-tailed) }\end{array}$ & $\begin{array}{c}\text { Mean } \\
\text { Difference }\end{array}$ & $\begin{array}{c}\text { Std. Error } \\
\text { Difference }\end{array}$ & 95\% Confidence Interval of the Difference \\
\hline Post-test I vs Post-test II & & & Lower & Superior \\
\hline E.C. Density & 3.302 & 40 & 0.002 & 1.809 & 0.547 & 0.702 & 2.916 \\
\hline C.G. Density & 0.528 & 40 & 0.601 & 0.285 & 0.541 & -0.808 & 1.379 \\
\hline E.G. Pressure & 4.006 & 40 & 0.000 & 2.285 & 0.570 & 1.132 & 3.439 \\
\hline
\end{tabular}

The significance values obtained for item 1 were 0.013 and 0.011 for item 2, as shown in Table 6. In both cases, the values are less than the 0.05 reference, so we can affirm that there are statistically significant differences between the results obtained by the control group compared to the results obtained in the experimental group, regardless of the chosen topic. This seems to indicate that students who have learned concepts using recreational physics have done so through a more meaningful and less rote learning that the students in the control group, who have forgotten over time the learned concepts. These results allow us to accept the Hypothesis 3 (H3): "The students from the experimental groups remember the concepts explained a longer time than the students from the control groups."

In order to check the effect size of the statistically significant differences found in the post-test II of the control and experimental groups, we calculated the value of Cohen's delta, represent by d (Cohen, 1988). For the density topic $\mathrm{d}=0.824$ and for the pressure topic $\mathrm{d}=0.656$. In both cases, the results reveal an effect size categorized in the literature as large.

To recap, in Figure 2 is shown the comparison of scores between the groups for each subject in the different assessment instruments used (Pre-test, Post-test I and Post-test II). We also notice that the results obtained in both topics are very similar, although they were obtained in different schools, which allows us to somehow extrapolate these results.

Table 7 shows the inferential analysis performed to compare the statistical differences between post-test I and post-test II in each of the groups.

We can observe in Table 7 that there are statistically significant differences (Sig. $<0.05$ ) between the average scores obtained in the two post-tests of the control groups, being the scores of post-tests II lower than those of posttests I in both topics (density and pressure). However, there are no statistically significant differences (Sig. > 0.05) between the average scores obtained in post-test I and II of the experimental groups. Therefore, as stated in hypothesis 3 , the students of the experimental groups still remember over time the concepts studied, as opposed to the students of the control groups. Likewise, the effect size calculated using Cohen's delta was large, therefore the statistical differences found were relevant. Specifically, a Cohen's delta d $=1.049$ was obtained for the differences in the control group for the density topic and a value of $d=1.349$ for the differences in the control group for the pressure topic.

Regarding the results of the affective-emotional domain of the study, during the different didactic interventions carried out the students from the different groups were asked about the emotions experienced in the classroom during the teaching of the contents. Emotions were selected based on the categorization of other authors and previous work (Dávila, Borrachero, Cañada, Martínez, \& Sánchez, 2015; Mellado et al., 2014). The students had to select between different emotions, both positive (joy, fun, enthusiasm, surprise and confidence) and negative (boredom, sadness, disgust, fear, nervousness and anger). 


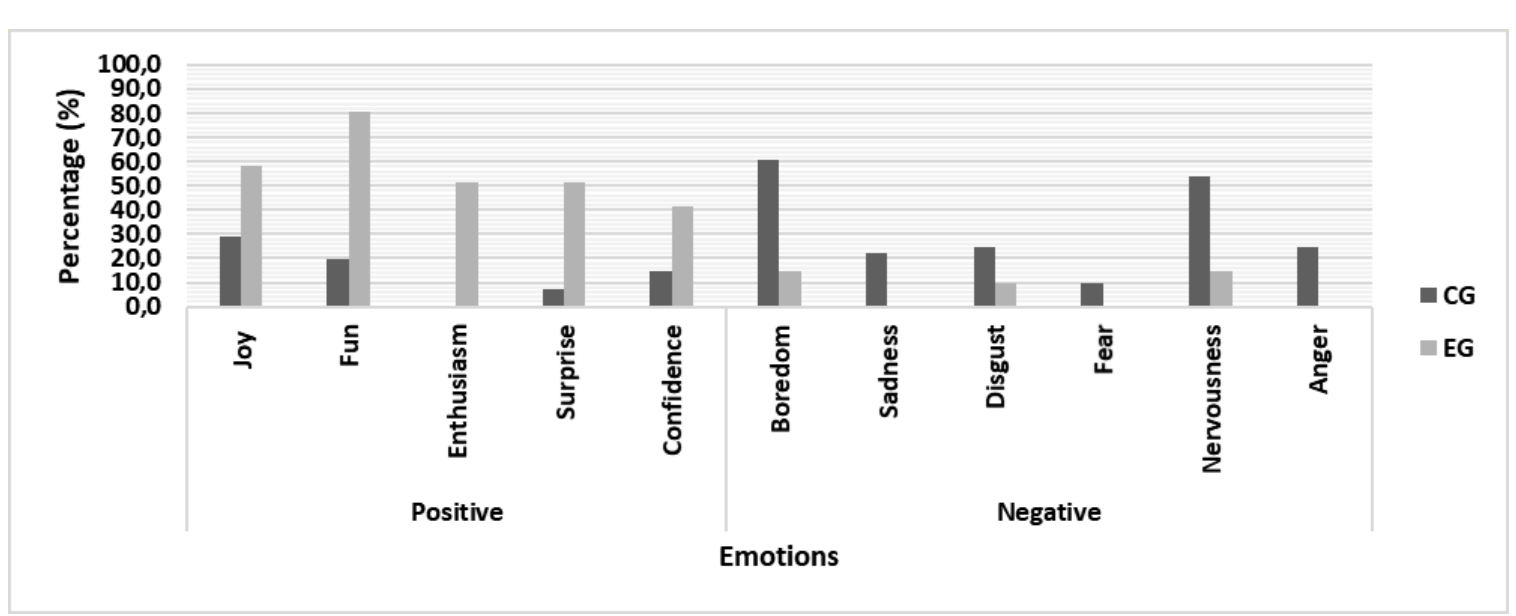

Figure 3. Emotions manifested by the students of the $G C$ and the EG

Figure 3 shows the percentage of students in each group (control and experimental) who reported feeling each emotion.

The results obtained revealed a higher frequency of positive emotions in the experimental groups and a higher frequency of negative emotions in the control groups. In general terms, the students in the experimental groups said they felt joy, fun, enthusiasm, surprise and confidence. However, students in the control groups were more likely to report emotions such as boredom, disgust or nervousness. An inferential statistical analysis (Student's ttest for independent samples) revealed statistically significant differences (Sig. < 0.05) in the different emotions between the two groups.

\section{DISCUSSION}

The average grades obtained at the beginning of the research indicate that the students had not previously worked on these concepts in the classroom, and that they did not have formal prior knowledge of them, which is evidenced by the results of the Pre-Test. The data obtained in Post-Test I verify that both the experimental and the traditional explanations are effective when it comes to assimilating the contents in the short term. It should be noted, however, that only the students belonging to the experimental group remembered the contents proposed in the experimental interventions over time, since they obtained better scores in Post-Test II, carried out several weeks after the explanations with experiments and Post-Test I. With this fact, we can confirm previous research (Abrahams \& Millar, 2008; Fortes, 1991; Jakar \& Baykara, 2014; Wallace, Tsoi, Calkin, \& Darley, 2003) highlighting the significance and benefits of the practical treatment of scientific content. Specifically, based on the results of the present research, the practices with a playful and recreational character in the primary school classroom are effective from both a cognitive and affective point of view, since they allow the promotion of an effective and lasting acquisition of the physical concepts explained.

We agree with Etkina (2000) that one of the most appropriate ways to build science in the primary school classroom is to carry out home experiences based on simple, everyday elements. However, it is necessary to bear in mind that the fundamental requirement is that the students are seriously involved in the learning process, because it is useless to follow practical activities if scientific knowledge is not extracted from them. As indicated in previous studies (Latorre \& Fortes, 1990), observation or classroom experience alone is not enough, nor is the expository educational process sufficient. Both methodologies are fundamental from a didactic point of view in the teaching-learning process, since it is the theoretical content that generates discussions, demands reflection, elaboration of hypotheses and critical spirit. Thus, teaching how to analyse the results and how to express them correctly promotes better science learning.

On the other hand, the results obtained by the experimental groups allow us to conclude that the inclusion of practical work or hands-on science activities leads the student to assimilate and learn in a more effective way the scientific contents in the classroom, thus lasting the learning over time. Although the members of the control group have also improved their scores after the traditional intervention, it was however promoted a more rote learning, which is forgotten over time, as evidenced by the results of the second post-test. We therefore consider it necessary to develop this kind of recreational science activities in the classroom, either as a replacement for the theoretical classes or as a complement to them. Likewise, as some authors point out (Carrascosa, Gil, \& Vilches, 2006), the experimental methodologies are considered more effective than the traditional ones because they will generate a positive attitude towards the theory and a more real vision of it. We agree with Hart, Mulhall, Berry, Loughran, and Gunstone (2000) that conducting experiments in schools motivates students and reinforces concepts with 
hypothesis formulation. Specifically, in the present research, the students in the experimental groups showed more interest and showed more positive emotions (such as joy, enthusiasm, fun or confidence) than those shown by the students in the control groups. In this sense, positive emotions can influence learning and improve student motivation (Tanveer, Shabbir, Ammar, Dolla, \& Aslam, 2012). These authors pointed out in their studies that emotions can make students' learning last more over time, so that funny learning positively affects students' memory. On the other hand, if the emotions are negative, students may approach scientific activities with apprehension and low confidence. This can cause a certain amount of stress in the students, which can lead to ineffective learning (Britner \& Pajares, 2006). For this reason, from a didactic point of view, and in accordance with the studies that highlight the importance of the affective and cognitive domain in science teaching (Mellado et al., 2014; Osborne, Simon, \& Collins, 2010), it is important to develop activities in the classroom that promote positive emotions towards the learning of scientific concepts. In this way, it is possible to contribute to promoting scientific vocations from an early age, which is so necessary for present and future society (Eurydice, 2006, 2011), thus avoiding the attitudinal decline that occurs in these subjects as the age of students increases (Vázquez \& Manasero, 2011). Above all, bearing in mind that one of the causes that can influence this is the teaching methodology used by the teachers (Borrachero, Gómez, \& Bermejo, 2013), this study shows that it is up to us to promote this type of active methodology to achieve fun and meaningful learning.

\section{CONCLUSIONS}

Alternative approaches to traditional teaching insist on the need for students to play a more active role in the classroom. The results of this study seem to indicate that establishing recreational and playful science practices, through the development of observation, hand-on activities and experimentation processes, will allow primary school students to develop research skills and abilities. These recreational experiences are an alternative to the simple memorization of scientific content and serve to apply theoretical notions in both formal and non-formal contexts, as well as to make students aware of the applicability of the content and its relationship with everyday life. As previous studies by Karacop and Doymus (2013) show, student-centred teaching methodologies, rather than teacher-centred teaching methodologies, promote students' motivation and interest in science, especially those based on inquiry, which lead students to formulate explanations based on argument and the use of evidence (AlakeTuenter et al., 2012). This is especially relevant in a society where there is a decreasing number of scientifictechnological vocations due to the decline in positive attitudes and emotions towards science subjects, as pointed out in various reports and research studies (NSB, 2004; OECD, 2006).

After the completion of this work we found that the traditional methodology can be reinforced with teaching methodologies that arouse more interest and enthusiasm in children, in order to learn concepts more significantly. Thus, science experiences with a more playful character (Buruluz, 2012) can be a very useful didactic tool that allows teachers to deal with the meaningful acquisition of the concepts explained to their students.

We believe that both methodologies can go together and support each other to motivate, teach and maintain the interest and knowledge of the student in science. With these experiences the monotony of conventional classroom breaks, and the attention of children is captured. They become interested in the field of physics, thus proving the didactic utility of recreational physics experiences in the elementary classroom. These activities seem very appropriate and interesting to complement the theoretical content of the course, even for our students, future elementary teachers, who lose their fear of teaching physics.

We consider that, despite the fact that the experimental sessions favour the acquisition of theoretical concepts, it is not possible to make a judgment on the application of this theoretical knowledge in real situations that show the development of scientific competences in the students, since no situations related to competence or to the student's daily life have been presented in this study. We believe it is important to carry out future research from this perspective in order to know not only the efficiency of the experimental methodologies in the retention of theoretical classroom contents but also their effectiveness in solving new problems applied to our students' daily life situations, in order to evaluate the applicability of the concepts explained through the different experiences.

\section{ACKNOWLEDGEMENTS}

The authors wish to thank Research Projects IB16068 (Junta de Extremadura / Fondo Europeo de Desarrollo Regional) and EDU2016-77007-R (Agencia Estatal de Investigación / Fondo Europeo de Desarrollo Regional). 


\section{REFERENCES}

Abrahams, I., \& Millar, R. (2008). Does practical work really work? A study of the effectiveness of practical work as a teaching and learning method in school science. International Journal of Science Education, 30(14), 1945-1969. https:/ / doi.org/10.1080/09500690701749305

Alake-Tuenter, E., Biemans, H. J. A., Tobi, H., Walls, A. E. J., Oosterheert, I., \& Mulder, M. (2012). Inquiry-Based Science Education Competencies of primary School Teachers: A literature study and critical review of the American National Science Education Standards. International Journal of Science Education, 34(17), 1-32. https:/ / doi.org/10.1080/09500693.2012.669076

Ausubel, D. P. (2000). The acquisition and retention of knowledge: a cognitive view. Dordrecht: Kluwer Academic Publishers. https:/ / doi.org/10.1007/978-94-015-9454-7

Ayvacı, H. Ş. (2010). A pilot survey to improve the use of scientific process skills of kindergarten children. Electronic Journal of Science and Mathematics Education, 4(2), 1-24.

Basheer, A., Hugerat, M., Kortam, N., \& Hofstein, A. (2016). The Effectiveness of Teachers' Use of Demonstrations for Enhancing Students' Understanding of and Attitudes to Learning the Oxidation-Reduction Concept. Eurasia Journal of Mathematics, Science and Technology Education, 13(3), 555-570. https://doi.org/10.12973/eurasia.2017.00632a

Borrachero, A. B., Gómez, R., \& Bermejo, M. L. (2013). Emociones ante las ciencias y sus posibles causas [Emotions towards science and their possible causes]. International Journal of Developmental and Educational Psychology, 25(2), 535-548.

Bozdoğan, A. E., \& Yalçın, N. (2009). Determining the Influence of a Science Exhibition Center Training Program on Elementary Pupils' Interest and Achievement in Science. Eurasia Journal of Mathematics, Science and Technology Education, 5(1), 27-34. https:// doi.org/10.12973/ ejmste/75254

Brígido, M., Borrachero, A. B., Bermejo, M. L., \& Mellado, V. (2013). Prospective primary teachers' self-efficacy and emotions in science teaching. European Journal of Teacher Education, 36(2), 200-217. https:/ / doi.org/10.1080/02619768.2012.686993

Britner, S. L., \& Pajares, F. (2006). Sources of science self-efficacy beliefs of middle school students. Journal of research in science teaching, 43(5), 485-499. https:/ / doi.org/10.1002/ tea.20131

Bulunuz, M. (2012). Motivational qualities of hands-on science activities for Turkish preservice kindergarten teachers. Eurasia Journal of Mathematics, Science \& Technology Education, 8(2), 73-82.

Bulunuz, M., \& Jarrett, S.O. (2009). Developing an interest in science: Background experiences of preservice elementary teachers. International Journal of Environmental and Science Education, 5(1), 65-84.

Carmichael, P., Driver, R., Holding, B., Phillips, I., Twigger, D., \& Watts, D. M. (1990). Research on Students' Conceptions in Science: A Bibliography. Leeds: University of Leeds.

Carrascosa, J., Gil-Pérez, D., \& Vilches, A. (2006). Papel de la actividad experimental en la educación científica [Role of experimental activity in science education]. Caderno Brasileiro de Ensino de Física., 23(2), 157-181.

Cohen, J. (1988). Statistical Power Analysis for the Behavioral Sciences. Second Edition. Hillsdate, NJ: Laurence Erlbaum. https:/ / doi.org/10.1002/bs.3830330104

Confederación de Sociedades Científicas de España, COSCE. (2011). Enseñanza de las Ciencias en la Didáctica escolar para edades tempranas en España (Enciende report) [Science teaching in school didactics for early ages in Spain (Turns report)]. Madrid, Spain: COSCE.

Costa, M. F., \& Dorrío, B. V. (2010). Actividades manipulativas como herramienta didáctica en la educación científico-tecnológica. Revista Eureka sobre Enseñanza y Divulgación de las Ciencias, 7(2), 462-472. https://doi.org/10.25267/Rev_Eureka_ensen_divulg_cienc.2010.v7.i2.01

Dávila, M. A., Borrachero, A. B., Cañada, F., Martínez, G., \& Sánchez, J. (2015). Evolución de las emociones que experimentan los estudiantes del grado de maestro en educación primaria, en didáctica de la materia y la energía [Evolution of the emotions experienced by students in the teacher's degree in primary education, in the subject of didactics of matter and energy]. Revista Eureka sobre Enseñanza y Divulgación de las Ciencias, 12(3), 550-564. https://doi.org/10.25267/Rev_Eureka_ensen_divulg_cienc.2015.v12.i3.12

Ding, C., \& Hershberger, S. (2002). Assessing content validity and content equivalence using structural equation modeling. Structural Equation Modeling: A Multidisciplinary Journal, 9(2), $283-297$. https:/ / doi.org/10.1207/S15328007SEM0902_7

Ding, L., \& Beichner, R. (2009). Approaches to data analysis of multiple-choice questions. Physical Review Special Topics-Physics Education Research, 5(2), 020103. https:/ / doi.org/10.1103/PhysRevSTPER.5.020103 
Ding, L., Chabay, R., Sherwood, B., \& Beichner, R. (2006). Evaluating an electricity and magnetism assessment tool: Brief electricity and magnetism assessment. Physical review special Topics-Physics education research, 2(1), 010105. https:/ / doi.org/10.1103/PhysRevSTPER.10.010105

Dorrío, B. V., Rodríguez, S., Fernández, J., Ansín, J. A., \& Lago, A. (2007). Ciencias en las manos: Aprendizaje informal. [Science in the hands: Informal learning]. Alambique, 52, 107-116.

Duit, R., \& Pfundt, H. (1998). Students' Alternative Frameworks and Science Education. Printed version and database. Kiel: IPN.

Duschl, R. A., Schweingruber, H. A., \& Shouse, A.W. (2007). Taking science to school: Learning and teaching science in grades K-8.Washington, D.C.: National Academy Press.

Esteves, Z., Cabral, A., \& Costa, M. F. M. (2008). Informal Learning in Basic Schools. Science Fairs. International Journal of Hands-on Science, 1(2), 23-27.

Etkina, E. (2000). The minilab as a tool in physics instruction. The Physics Teacher, 38, 136-138. https:/ / doi.org/10.1119/1.880474

European Commission. (2004). Europe needs More Scientists: Report by the High Level Group on Increasing Human Resources for Science and Technology. Brussels: European Commission.

European Commission. (2007). Science Education Now: A renewed pedagogy for the future of Europe. Brussels: European Commission

Eurydice. (2006). Science teaching in schools in Europe. Brussels: Eurydice.

Eurydice. (2011). Science Education in Europe: National Policies, Practices and Research. Brussels: Eurydice.

FECYT. (2014). Percepción social de la ciencia y la tecnología [Social perception of science and technology]. España: Fundación Española para la ciencia y la tecnología.

Fortes, M. (1991). Desarrollo del niño y experimentación en ciencias [Child development and experimentation in science]. Revista de psicologia de la educacion, 6, 65-89.

Fortus, D., \& Vedder-Weiss, D. (2014). Measuring students' continuing motivation for science learning. Journal of Research in Science Teaching, 51(4), 497-522. https:/ / doi.org/10.1002/tea.21136

Francl, M. (2012). Homemade chemists. Nature Chemistry, 4, 687-690. https:/ / doi.org/10.1038/nchem.1441

García Barros, S., \& Martínez Losada, C. (2003). Análisis del trabajo práctico en textos escolares de Primaria y Secundaria [Analysis of practical work in primary and secondary school textbooks]. Enseñanza de las Ciencias (Núm. Extraordinario) 5-16.

García Molina, R. (2011). Ciencia recreativa: un recurso didáctico para enseñar deleitando [Recreational science: a didactic resource for delightful teaching]. Revista Eureka sobre Enseñanza y Divulgación de las Ciencias, 8 (Núm. Extraordinario), 370-392. https:/ / doi.org/10.25267/Rev_Eureka_ensen_divulg_cienc.2011.v8.iextra.02

Garritz, A. (2005). Debate sobre cómo cambiar los textos de química para el siglo XXI [Debate on how to change chemistry texts for the 21 ${ }^{\text {st }}$ century]. Educación Química, 16(3), 363-369.

Hart, C., Mulhall, P., Berry, A., Loughran, J., \& Gunstone, R. (2000). What is the purpose of this experiment? Or can students learn something from doing experiments? Journal of Research in Science Teaching, 37(7), 655-675. https:/ / doi.org/10.1002/1098-2736(200009)37:7<655::AID-TEA3>3.0.CO;2-E

Hodson, D. (1992). In search of a meaningful relationship: an exploration of some issues relating to integration in science and science education. International Journal of Science Education, 14(5), 541-566. https:/ / doi.org/10.1080/0950069920140506

Hodson, D. (1993). Rethinking old ways: Towards a more critical approach to practical work in school science. Studies in Science Education, 22, 85-142. https:/ / doi.org/10.1080/03057269308560022

Karacop, A., \& Doymus, K. (2013). Effects of Jigsaw Cooperative Learning and Animation Techniques on Student's Understanding of Chemical Bonding and Their Conceptions of the Particulate Nature of Matter. Journal of Science Education and Technology, 22, 186-203. https:/ / doi.org/10.1007/s10956-012-9385-9

Kelly, J. (2000). Rethinking the elementary science methods course: a case for content, pedagogy and informal science education. International Journal of Science Education, 22, 755-777. https:/ / doi.org/10.1080/09500690050044080

Kline, P. (2015). A handbook of test construction (psychology revivals): introduction to psychometric design. New York. Routledge.

Latorre, A., \& Fortes, C. (1990). Modelos en psicología de la educación y su aplicación a la enseñanza-aprendizaje de las ciencias-experimentales [Models in the psychology of education and their application to the teaching and learning of the experimental sciences]. Didáctica de las ciencias experimentales y sociales, 4, 57-61. 
Leibham, M. B., Alexander, J. M., \& Johnson, K. E. (2013). Science interests in preschool boys and girls: Relations to later self-concept and science achievement. Science Education, 97(4), 574-593. https://doi.org/10.1002/sce.21066

Lewin, W. (2011). For the love of physics. From the end of the rainbow to the edge of time. A journey through the wonders of physics. New York. Free Press

Lozano, O., Garcia-Molina, R., \& Solbes, J. (2007). Cuatro juegos que ilustran la conservación de la energía [Four games that illustrate energy conservation]. Alambique. Didáctica de las Ciencias Experimentales, 54, 115-118.

Mantzicopoulos, P., Patrick, H., \& Samarapungavan, A. (2008). Young children's motivational beliefs about learning science. Early Childhood Research Quarterly, 23(3), 378-394. https:// doi.org/10.1016/j.ecresq.2008.04.001

Martínez, G., Naranjo, F. L., Pérez, A. L., Suero, M. I., \& Pardo, P. J. (2017). Meaningful learning Theory in science education: just another pedagogical trend? Journal of Sciene Education, 18(1), 19-23.

Marulanda, J. I. \& Gómez, L. A. (2006). Experimentos en el aula de clase para la enseñanza de la física [Classroom experiments for teaching physics]. Revista de la Sociedad Colombiana de Física, 38(2), 699-702.

McColgan, M. W., Finn, R. A., Broder, D. L., \& Hassel, G. E. (2017). Assessing students' conceptual knowledge of electricity and magnetism. Physical Review Physics Education Research, 13(2), 020121. https:/ / doi.org/10.1103/PhysRevPhysEducRes.13.020121

McComas, W. F. (2011). Science Fair. The Science Teacher, 78(8), 34-38

Mellado, V., Borrachero, A. B., Brígido, M., Melo, L.V., Dávila, M.A., Cañada, F., ... Bermejo, M. L. (2014). Las emociones en la enseñanza de las ciencias [Emotions in science education]. Enseñanza de las Ciencias, 32(3), 11-36.

Melo, L. V., Sánchez, R., Cañada, F., \& Martínez, G. (2016). Dificultades del aprendizaje sobre el principio de Arquímedes en el contexto de la flotación [Learning difficulties on the Archimedes principle in the context of flotation]. Revista Brasileira de Ensino de Física, 38(4), e4401. https://doi.org/10.1590/1806-9126-RBEF2016-0077

Millar, R. (2010). Practical works. In J. Osborne \& J. Dillon (Eds.), Good practice in science teaching. What research has to say (pp. 108-134). New York, NY: Open University Press.

Murphy, C., \& Beggs, J. (2003). Children's perceptions of school science. School Science Review, 84, 109-116.

Novak, J. D. (1985). Metaleaming and Metaknowledge Strategies to Help Students Learn How to Learn. In L. West \& L. Pines (eds.), Cognitive Structure and Conceptual Change. (In the Educational Psychology Series). (Academic Press: Orlando, Florida), 189-209.

Novak, J. D. (1998). Learning, creating and using knowledge: Concept maps as facilitative tools in schools and corporations. Mahwah, NJ: Lawrence Erlbaum Associates.

NSB (2004). Science and Engineering Indicators 2004 (NSB 04-01). Arlington, VA: National Science Board, National Science Foundation. Retrieved from https://www.nsf.gov/nsb/documents/reports.htm

OECD (Organisation for Economic Co-operation and Development). (2006). Evolution of Student Interest in Science and Technology Studies Policy Report. Global Science Forum. May 2006. OECD, Paris.

Olsen, R. V., Prenzel, M., \&Martin, R. (2011). Interest in science: A many-faceted pictures painted by data from the OECD PISA study. International Journal of Science Education, 33(1), 1-6. https://doi.org/10.1080/09500693.2010.518639

Oppermann, E., Brunner, M., Eccles, J. S., \& Anders, Y. (2018). Uncovering young children's motivational beliefs about learning science. Journal of Research in Science Teaching, 55(3), 399-421. https://doi.org/10.1002/tea.21424

Osborne, J., Simon, S., \& Collins, S. (2010) Attitudes towards science: A review of the literature and its implications, International Journal of Science Education, 25(9), 1049-1079. https:/ / doi.org/10.1080/0950069032000032199

Palmer, D. (2009). Student interest generated during an inquiry skills lesson. Journal of Research in Science Teaching, 46(2), 147-165. https:/ / doi.org/10.1002/tea.20263

Paul, J., Lederman, N. G., \& Groß, J. (2016). Learning experimentation through science fairs. International Journal of Science Education, 38(15), 2367-2387. https:/ / doi.org/10.1080/09500693.2016.1243272

Rocard, M., Csermely, P., Jorde, D., Lenzen, D., Walberg, H., \& Hemmo, V. (2007). Science education now: A renewed pedagogy for the future of Europe. Brussels, Belgium: Directorate General for Research, Science, Economy and Society. 
Saçkes, M., Trundle, K. C., Bell, R. L., \& O'Connell, A. A. (2011). The influence of early science experience in kindergarten on children's immediate and later science achievement: Evidence from the early childhood longitudinal study. Journal of Research in Science Teaching, 48(2), 217-235. https:/ / doi.org/10.1002/ tea.20395

Simpkins, S. D., Davis-Kean, P. E., \& Eccles, J. S. (2006). Math and science motivation: A longitudinal examination of the links between choices and beliefs. Developmental Psychology, 42(1), 70-83. https:/ / doi.org/10.1037/0012-1649.42.1.70

Strike, K. A., \& Posner, G. J. (1990). A revisionist theory of conceptual change. In R. Duschl \& R. Hamilton (eds.). Philosophy of Science, Cognitive Science and Educational Theory and Practice. Albany, Nueva York: SUNY Press.

Tanveer, M. A., Shabbir, M. F., Ammar, M., Dolla, S. I., \& Aslam, H. D. (2012). Influence of Teacher on Student' Learning Motivation in Management Sciences Studies. American Journal of Scientific Research, 67(1), 76-87

Toplis, R., \& Allen, M. (2012). 'I do and I understand?' Practical work and laboratory use in United Kingdom schools. Eurasia Journal of Mathematics, Science \& Technology Education, 8(1), 3-9

Vázquez, A., \& Manassero, M. A. (2011). El descenso de las actitudes hacia la ciencia de chicos y chicas en la educación obligatoria [The decline in boys' and girls' attitudes towards science in compulsory education]. Ciencia E Educaçao, 17(2), 249-268.

Wallace, C. S., Yin Tsoi, M., Calkin, J., \& Darley, M. (2003). Learning from inquiry-based laboratories in nonmajor biology: An interpretive study of the relationships among inquiry experience, epistemologies, and conceptual growth. Journal of Research in Science Teaching, 40(10), 986-1024. https:/ / doi.org/10.1002/tea.10127

Yakar, Z., \& Baykara, H. (2014). Inquiry-based laboratory practices in a science teacher training program. Eurasia Journal of Mathematics, Science \& Technology Education, 10(2), 173-183.

\section{http://www.ejmste.com}

